\title{
The influence of socio-demographic and clinical factors on the process of acceptance of the disease among patients with ulcerative colitis
}

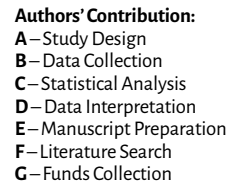

F-Literature Search
G-Funds Collection

\author{
Joanna Chrobak-Bień ${ }^{1 A B C D E F}$, Anna Gawor ${ }^{2 A D F}$, Małgorzata Paplaczyk ${ }^{3 A D F}$, Ewa Małecka-Panas ${ }^{4 A D F}$, \\ Anita Gąsiorowska ${ }^{5 A D E}$ \\ 'Klinika Chorób Przewodu Pokarmowego, Uniwersytecki Szpital Kliniczny nr 1 w Łodzi. Studia doktoranckie, Wydział Lekarski, \\ Uniwersytet Medyczny w Łodzi, Kierownik: prof. Ewa Małecka-Panas \\ 'Zakład Pielęgniarstwa Internistycznego i Środowiskowego, Wydział Nauk o Zdrowiu, Uniwersytet Jagielloński, Collegium \\ Medicum, Kraków, Kierownik: prof. Tomasz Brzostek \\ ${ }^{3}$ Studia doktoranckie, Wydział Nauk o Zdrowiu, Uniwersytet Jagielloński, Collegium Medicum, Zakład Fizjologii Medycznej, \\ Kraków, Kierownik: prof. Jolanta Jaworek \\ ${ }^{4}$ Klinika Chorób Przewodu Pokarmowego, Uniwersytecki Szpital Kliniczny nr 1 w Łodzi, Uniwersytet Medyczny w Łodzi, \\ Kierownik: prof. Ewa Małecka- Panas \\ ${ }^{5}$ Klinika Gastroenterologii , Uniwersytet Medyczny w Łodzi, Uniwersytecki Szpital Kliniczny im. WAM-CSW, Kierownik: prof. Anita Gąsiorowska
}

Article history: Received: 28.03.2018 Accepted: 26.06.2018 Published: 06.08.2018

ABSTRACT: $\quad$ Introduction: Ulcerative colitis (UC) belongs to the group of inflammatory bowel diseases of previously unknown etiology Although UC may occur at any age, the peak of incidence falls between the ages of 20 and 40 and over 65 . It is characterized by alternating periods of remission and exacerbations that hinder the daily functioning of patients.

The aim: The aim of the study was to determine the degree of acceptance of the disease among WZJC patients, depending on selected socio-demographic and clinical variables.

Material and methods: The study was conducted on a group of 50 patients with confirmed UC, treated at the Ceneral and Colorectal Surgery Clinic of the Medical University in Lodz, and under the care of a specialist Gastroenterological Outpatient Clinic at the University Hospital No. 1 in Łódź. The study was conducted using the own structure questionnaire and the Acceptance of IIIness Scale (AIS).

Results: Young people predominated in the study group. The average age of respondents was 38,82 . Analysis of the results showed a reduced degree of acceptance of the disease among patients in the phase of exacerbation of the disease. The mean point score of the AIS scale for the study group was 29,65 , which indicates the average level of acceptance of the disease among respondents.

Conclusions: People with higher education, professionally active and treated conservatively, accepted their illness to a better extent. The influence of having offspring on better adaptation to the disease has not been demonstrated.

KEYWORDS:

acceptance of the disease, ulcerative colitis

\section{INTRODUCTION}

Ulcerative colitis (UC) is a kind of inflammatory bowel disease involving rectal mucosa, or the rectum with colon, resulting in ulcerations in some cases. It is incurable and varies with periods of exacerbation and remission.

The disease affects mainly population of highly-developed European or North American nations. It can relatively rarely be observed in South America, Asia and Africa. It is estimated that morbidity and incidence in those regions is about 10 times lower than in Europe and North America [1,2]. The incidence of UC in Europe is approximately 10 new cases per 100,000 people annually [3]. In Poland, epidemiology assessment is difficult due to a lack of reliable statistics. In Lower Silesia, 840 hospitalizations for UC on average are registered annually [4,5]. In UC pathogenesis, genetic, environmental and immunologic factors play an important role. $\mathrm{UC}$ can occur at any age, however, the peak incidence is observed between ages 20 and 40 and over 65 [6].

$\mathrm{UC}$ is incurable and accompanies the patient through the rest of his/her life. It varies with periods of exacerbation and remission, which impair everyday activities and lower patient's quality of life. As a consequence, the patient generally feels bad, which is not only caused by gastrointestinal symptoms but also by emotional and psychological issues [7]. Nowadays, a clear tendency can be observed in medicine to include health and disease-related issues in biopsychosocial context, including social and psychological factors affecting the course of the disease. The assessment of such factors brings up a broader perspective on patient's health problems [8].

Adjustment to the disease is important in many chronic diseases, which demand a change of the patient's attitude and taking aspects such as acceptance of one's disease into consideration [9]. The term 'acceptance' denotes adopting an opinion, judgment, belief, behavior, favorable attitude or to give a consent [10]. Accepting one's disease means adjusting to limitations posed by it and accepting the associated disability. The consequences include accepting the limitations, not being self-sufficient, dependence on others and low self-esteem [11]. In a chronic and difficult therapeutic process, medical staff play the key role, in addition to other patient's support. Bonding with other patients is an important regulating factor in the emotional sphere, while psychological counseling can turn out beneficial in accepting one's new difficult life situation. 
The aim of the study was to evaluate the acceptance of the disease in patients with ulcerative colitis with respect to selected socio-demographic and clinical variables.

\section{MATERIALS AND METHODS}

Fifty patients diagnosed with ulcerative colitis residing in Łódź Voivodeship were included in the study. The group of 25 respondents consisted of patients hospitalized at the Department of General and Colorectal Surgery, Medical University in Łódź. The remaining 25 individuals were patients of the Gastroenterology Clinic of the 1st University Hospital in Łódź. The enrollment was voluntary and anonymous, and the respondents were informed about it beforehand. The study was commenced in July 2016, after obtaining the acceptance by the Bioethical Committee of the Medical University in Łódź (RNN/177/16/KE, June 14th, 2016) and terminated on January 31st, 2017.

In the study, self-constructed questionnaire along with the Acceptance of Illness Scale (AIS) adapted by Z. Juczyński were implemented [12]. Our questionnaire covered socio-demographic (sex, age, place of stay, education, occupational activity, offspring) and clinical data (duration of disease, therapy, additional symptoms).

The acceptance was measured using AIS scale. The scale contains 8 statements, which reflect negative consequences of the disease and regard the following: limitations, being self-sufficient, self-esteem, enjoying one's interests and the patient's view on other people's perception towards his/her disease. The answer was evaluated on a 5-point Likert scale ( 1 - absolutely agreed, 5 - absolutely disagreed). The sum ranged from 8 to 40 and reflected patient's acceptance level. Low score reflects lack of acceptance, while high score is associated with high acceptance of one's disease. Score 20 points or less means no or poor acceptance. Score within the range of 20 to 30 points reflects medium level of accept, and patients scoring over 30 points accept their disease at high level or fully. The statistical analysis of quantitative variables (i.e. expressed as numbers) was conducted by calculating the mean, standard deviation, median, quartiles, minimal and maximal value.

The analysis of qualitative variables (i.e. not expressed as numbers) was conducted by calculating the number and frequency of each value. The quantitative values were compared between two groups by using Student's t-test (for variables with normal distribution) or Mann-Whitney U-test (for non-normal distribution). Three or more groups of variables were compared using the analysis of variance (ANOVA) for normal distribution or Kruskal-Wallis test for non-normal distribution. When a difference turned out to be statistically significant, the post hoc analysis was conducted with either HSD Tukey's range test (for normal distribution) or Dunn's test (for non-normal distribution). The normality of distribution was tested with Shapiro-Wilk test. The significance level was set at 0.05 . Therefore, all $\mathrm{P}<0.05$ were interpreted as statistically significant. The analysis was carried out with R v. 3.3.2.

\section{RESULTS}

The collected results were subjected to statistical analysis, processed and presented in tables and charts.
In our study, 50 patients with ulcerative colitis were involved, including 20 females and 30 males. The mean age was 38.82 . All respondents were adults, their age ranging between 21 and 76 . The shortest course of the disease was 2 years and the longest was 17 years. The majority of the interviewees (92\%) declared living in a city. Many patients (52\%) had higher education, $32 \%$ secondary and $16 \%$ vocational degree. More than a half (56\%) were professionally active, $26 \%$ were on social benefits due to their inability to work, $12 \%$ were in training and $6 \%$ were on pension. During the study, $56 \%$ patients experienced an exacerbation, $40 \%$ were in remission, and two individuals had a mild form of the disease. Detailed clinical characteristics of the study group are shown in Table 1.

In the study group, the mean AIS score was 29.65 (SD = 7.06), which demonstrates medium level of disease acceptance. In this group, 6 patients scored 20 points or less, 18 patients -21 to 30 points, 26 patients -31 to 40 points. The highest score was 40 , and the lowest was 14 . The median was 32 points, meaning that half of the respondents scored 32 points or less, and the other half scored 32 points or more. The first and third quartiles were 24 and 35.75 points respectively. It means that a typical score was 24 to 35.75 points.

On further analysis, the acceptance was measured depending on the stage of the disease, at which the patients were starting the study. The AIS score distribution was non-normal, and thus the analysis was conducted using the Mann-Whitney U-test. $\mathrm{P}<0.05$ means that the disease acceptance among patients depended on the stage of the disease. Among patients with remission, the score was higher compared to those with exacerbation. The results are presented in Table 2.

The statistical analysis showed no correlation between sex and disease acceptance. Also, age was subject to analysis. It has not been demonstrated that age affects disease acceptance. The results are shown on Charts 1 and 2.

Later, we investigated the influence of educational level and occupational activity on disease acceptance in the study group. Among 50 patients, only 8 people had vocational education, and so they were merged with those with secondary education. It has been established that patients with higher education show better disease acceptance than those with secondary or vocational $(\mathrm{P}<$ 0.05) (Chart 3).

In the study group, only 6 patients were in training and 3 on pension. Those patients were merged with patients on social benefits, together forming an 'unemployed' group. It has been established that disease acceptance level depends on occupational activity. In employed patients, it was higher compared to the unemployed. The results are graphically shown in Chart 4.

In the next step, the influence of clinical symptoms (both gastrointestinal and extraintestinal) and therapy on disease acceptance among patients was evaluated. It has been established that clinical symptoms did not affect the disease acceptance, but conversely the influence of therapy on disease acceptance has been proven. The AIS score distribution was non-normal, and therefore the statistical analysis was conducted using the Kruskal-Wallis test. The $\mathrm{P}$-value $<0.05$ means that the disease acceptance level depended on the type of treatment (medical, surgical). In order to answer the 
Tab. I. Clinical characteristics of the study group

\begin{tabular}{|c|c|c|c|}
\hline FEATURE & & $\mathbf{N}$ & $\%$ \\
\hline \multirow{3}{*}{ Disease activity } & Mild & 2 & $4 \%$ \\
\hline & Remission & 20 & $40 \%$ \\
\hline & Exacerbation & 28 & $56 \%$ \\
\hline \multirow{2}{*}{ Disease impact on work } & Yes & 11 & $22 \%$ \\
\hline & No & 39 & $78 \%$ \\
\hline \multirow{2}{*}{ Need to change job due to disease } & Yes & 11 & $22 \%$ \\
\hline & No & 39 & $78 \%$ \\
\hline \multirow{4}{*}{ Disease impact on personal relationships } & Very strong & 2 & $4 \%$ \\
\hline & Strong & 7 & $14 \%$ \\
\hline & Little & 15 & $30 \%$ \\
\hline & None & 26 & $52 \%$ \\
\hline \multirow{4}{*}{ Disease impact on family relationships } & Very strong & 0 & ०\% \\
\hline & Strong & 0 & ०\% \\
\hline & Little & 21 & $42 \%$ \\
\hline & None & 29 & $58 \%$ \\
\hline \multirow{4}{*}{ Satisfaction with intimate life } & Very satisfied & 5 & $10 \%$ \\
\hline & Satisfied & 22 & $44 \%$ \\
\hline & Neither satisfied nor dissatisfied & 21 & $42 \%$ \\
\hline & Dissatisfied & 2 & $4 \%$ \\
\hline \multirow{5}{*}{ Source of knowledge on disease * } & TV, Internet & 33 & $66 \%$ \\
\hline & Physician, nurse & 50 & $100 \%$ \\
\hline & Other patients & 5 & $10 \%$ \\
\hline & Books, press & 21 & $42 \%$ \\
\hline & Other (university, Internet) & 3 & $6 \%$ \\
\hline \multirow{2}{*}{ Member of association } & Yes & 3 & $6 \%$ \\
\hline & No & 47 & $94 \%$ \\
\hline \multirow{8}{*}{ Pharmacology* } & Sulfasalazine & 9 & $18 \%$ \\
\hline & Mesalazine & 34 & $68 \%$ \\
\hline & Encorton [hydrocortisone] & 18 & $36 \%$ \\
\hline & Metypred [methylprednisolone] & 5 & $10 \%$ \\
\hline & Cortiment [budesonide] & 9 & $18 \%$ \\
\hline & Budenofalk [budesonide] & 3 & $6 \%$ \\
\hline & Infliximab & 6 & $12 \%$ \\
\hline & Adalimumab & 8 & $16 \%$ \\
\hline \multirow{10}{*}{ Symptoms * } & Perianal fistulas & 6 & $12 \%$ \\
\hline & Internal fistulas & 4 & $8 \%$ \\
\hline & Anal fissure & 4 & $8 \%$ \\
\hline & Abscess & 9 & $18 \%$ \\
\hline & Intestinal obstruction & 16 & $32 \%$ \\
\hline & Anemia & 16 & $32 \%$ \\
\hline & Skin lesions & 11 & $22 \%$ \\
\hline & Joint inflammation & 11 & $22 \%$ \\
\hline & Iritis & 4 & $8 \%$ \\
\hline & None of the above & 15 & $30 \%$ \\
\hline \multirow{4}{*}{ Surgeries due to disease } & None & 28 & $56 \%$ \\
\hline & 1 time & 9 & $18 \%$ \\
\hline & 2 times & 10 & $20 \%$ \\
\hline & 3 times & 3 & $6 \%$ \\
\hline
\end{tabular}


Tab. I. c.d. Clinical characteristics of the study group.

\begin{tabular}{|c|c|c|c|}
\hline FEATURE & & $\mathbf{N}$ & $\%$ \\
\hline \multirow{6}{*}{ Type of surgery* } & Small intestinal resection & 4 & $8 \%$ \\
\hline & Large intestinal resection & 16 & $32 \%$ \\
\hline & Abscess & 11 & $22 \%$ \\
\hline & Inflammatory abdominal pseudotumor & 2 & $4 \%$ \\
\hline & Fistulas & 6 & $12 \%$ \\
\hline & Other (ilestomy) & 3 & $6 \%$ \\
\hline
\end{tabular}

Total number of patients: $\mathrm{N}=50$

* The percentages do not sum up to $100 \%$, because it was a multiple-choice question.

Tab. II. Disease stage and level of acceptance.

\begin{tabular}{|c|c|c|c|c|c|c|c|c|}
\hline \multirow{2}{*}{ DISEASE STACE } & \multicolumn{8}{|c|}{ AIS [POINTS] } \\
\hline & $\mathbf{N}$ & MEAN & SD & MEDIAN & MIN. & MAX. & Q1 & Q3 \\
\hline Exacerbation & 30 & 26,93 & 6,3 & 28 & 14 & 37 & 22 & 32,75 \\
\hline Remission & 20 & 33,71 & 6,23 & 36,5 & 18 & 40 & 28,75 & 38 \\
\hline
\end{tabular}

*Mann-Whitney U test

Q1, Q3- quartiles

Tab. III. Prevalence of symptoms and disease acceptance.

\begin{tabular}{lllllll} 
SYMPTOMS & AIS [POINTS] & & & & & \\
& N & MEAN & SD & MEDIAN & MIN. & MAX. \\
None & 15 & 31,47 & 6,86 & 32 & 21 & 40 \\
Present & 35 & 28,87 & 7,09 & 29 & 14 & 39 \\
\hline
\end{tabular}

*Mann-Whitney U test

Q1, Q3-quartiles

Tab. IV. Surgical treatment and disease acceptance.

\begin{tabular}{|c|c|c|c|c|c|c|c|c|}
\hline \multirow{2}{*}{ LECZENIE CHIRURGICZNE } & \multicolumn{8}{|c|}{ AIS [POINTS] } \\
\hline & $\mathbf{N}$ & MEAN & SD & MEDIAN & MIN. & MAX. & Q1 & Q3 \\
\hline None & 21 & 31,63 & 5,3 & 32 & 24 & 40 & 28 & 37 \\
\hline 1 & 9 & 25,78 & 8,03 & 22 & 18 & 37 & 21 & 36 \\
\hline $2-3$ & 13 & 26,08 & 7,66 & 24 & 14 & 37 & 19 & 33 \\
\hline
\end{tabular}

*Kruskal-Wallis test + post hoc analysis (Dunn's test)

Q1, Q3- quartiles

question what exactly the relation is like, we performed the post hoc analysis. It showed that patients who did not undergo surgical treatment better accepted their disease than those operated on 2 or 3 times. The results are shown in Tables 3 and 4.

The last part of the study was to evaluate the effect of having children on patient's disease acceptance. The AIS score did not show normal distribution and therefore was analyzed using the Mann-Whitney U-test. For P > 0.05, the acceptance level was not influenced by offspring possession. The results are shown in Table 5.

\section{DISCUSSION}

Ulcerative colitis is a chronic disease and, as it is incurable, poses a serious challenge for the patient and his/her family. Such a diagnosis necessitates changes in everyday life rhythm, and sometimes it prohibits previous duties and social roles [13]. An important factor affecting life satisfaction in UC patients is patient's attitude towards the disease and correct evaluation of one's health. Full ac- ceptance means that the patient accepts himself/herslef in the role of a sick person. The best attitude to the disease is the congruent attitude, i.e. when the patient is aware of their disease and behaves rationally, accepts the diagnosis and complies to recommendations, and their perception of the disease converges with their physician's viewpoint [14]. Such an attitude is particularly hard to achieve for patients with UC. An important factor in adjusting to the new situation is age. Many UC patients are young people, who are still in school or just starting their adult lives. Such a diagnosis is thus a huge challenge and in order to function normally, they should accept it. Many authors emphasize the positive value of disease acceptance, which yields benefits from better psychological and physical well-being $[15,16,17]$. The time needed for complete acceptance is individual. Accepting one's disease by UC patients reduces their negative emotions and so raises their quality of life. In our study, mean AIS in the study group was 29.65 points, which shows that respondents accepted their disease at a medium level.

Our study showed that disease stage strongly affects disease acceptance, and hence lowers quality of life. Spanish researchers 
Tab. V. Offspring possession and disease acceptance.

\begin{tabular}{|c|c|c|c|c|c|c|c|c|}
\hline \multirow{2}{*}{ CHILDREN } & \multicolumn{8}{|c|}{ AIS [POINTS] } \\
\hline & $\mathbf{N}$ & MEAN & SD & MEDIAN & MIN. & MAX. & Q1 & Q3 \\
\hline Present & 29 & 30,08 & 6,14 & 29 & 18 & 40 & 26 & 35 \\
\hline None & 21 & 29,05 & 8,29 & 32 & 14 & 39 & 22 & 36 \\
\hline
\end{tabular}

*Mann-Whitney U test

Q1, Q3-quartiles

Casellas et al. [18] in their study showed that lower quality of life can be observed in patients with active disease rather than in those with remission, which can result from low disease acceptance.

Despite UC involving all age groups, in majority of cases it affects mainly young adults aged 20 to 40 . In our study, most respondents were young people, mean female age being 38.05 and male -39.33 . Glińska et al. [13] in their study established that older patients better adapt to living with inflammatory bowel disease. The authors explain this phenomenon by a more stable and grounded financial situation as well as professional status. Unfortunately, this observation has not been confirmed in our study.

In our study, we did not find any relationship between age and disease acceptance. The mean score for males (29.87) was only slightly higher than that for females (29.32), without any statistical significance. Those results are in accordance with other authors reports, who did not confirm better disease acceptance by men or women [13]. Next, we investigated the influence of education level on disease acceptance, and we established that patients with higher education better accept their disease. Also, Andrzejewska et al. [18] in her study showed better outcomes in disease accepting process in university graduates. Glińska et al. [13] reported strong influence of high education level on adequate disease acceptance as well.

Another socio-demographic factor potentially affecting the disease acceptance in UC patients was their occupational activity. Petryszyn et al. [19] in their study reported data indicating that in Poland 35\% males and 42\% females with UC end their professional life before the retirement age [19]. The authors also noted that the inability to work was 2.8 times higher among women and 2.6 times higher in men compared to their healthy peers. In ano- ther study by Bernklev et al. [20], the authors proved that within 5 years since the diagnosis, $11.7 \%$ respondents were unemployed due to an illness-related inability to work. Recurrent exacerbations result in a long-term or complete inability to work. As a consequence, the disease reduces patient's economic status and quality of life, which makes accepting the disease even more difficult. Glińska et al. [13] reported a considerably higher disease acceptance among professionally active respondents compared to those on social benefits or unemployed.

The acceptance of the disease and quality of life in UC patients is not only affected by the type of disease, but also by the time it occurs, kind of treatment and comorbidities. Sometimes it is impossible for UC patients to avoid surgery. In the study by Bączyk et al. [21], it was established that patients with inflammatory bowel disease undergoing surgical treatment show low quality of life and accept their disease to a lesser extent. Also, the statistical analysis in our study showed that patients, in whom surgery was not necessary, better accept their disease compared to surgically treated patients.

\section{CONCLUSIONS}

1. In the study group, we showed medium level of disease acceptance.

2. The acceptance was influenced by the stage of the disease. Patients with exacerbation had lower acceptance.

3. Patients with higher education, professionally active and receiving medical therapy were more inclined to accepting diagnosis of UC.

4. No significant relationship has been found between sex or age and disease acceptance.

\section{REFERENCES:}

1. Lakatos P.L.: Recent trends in the epidemiology of inflammatory bowel diseases: up or down? World J. Gastroenterol. 2006; 12: 6102-6108.

2. The history of IBD. http://web.uct.ac.za/depts/git/ibd//history.htm; data pobrania: 10.09.2015.

3. Eder P., Łodyga M., Łykowska-Szuber L., Bartnik W., Durlik M., Gonciarz M., Kłopocka M., Linke K., Małecka-Panas E., Radwan P., Rydzewska G.: Wytyczne Grupy Roboczej Konsultanta Krajowego w dziedzinie Gastroenterologii i Polskiego Towarzystwa Gastroenterologii dotyczące postępowania z pacjentem z wrzodziejącym zapaleniem jelita grubego. Przegl. Gastroenterol. 2013; 8 (1): 1-20.

4. Petryszyn P., Semianów-Wejchert J., Annabhani A., Paradowski L.: Jakość życia wykształcenie, profil zawodowy i status społeczny pacjentów z nieswoistymi zapaleniami jelit - przegląd piśmiennictwa. Gastroenterol. Pol. 2008; 15 (6): 421-424.

5. Paradowski L., Błachut K., Kollbek P.: Epidemiologia nieswoistych zapaleń jelit, skala problemu. Med. Dypl. 2007; supl. 5: 33-37.

6. Stanisławska J., Zubrzycka R., Talarska D.: Jakość życia chorych z wrzodziejącym zapaleniem jelita grubego z uwzględnieniem czynników demograficznych i klinicznych. Problemy Pielęgniarstwa. 2015; 23 (3): 373-379.

7. Jakubowska-Burek L., Warmuz- Stangierska I., Kaczmarek E. i wsp.: Ocena jakości życia u polskich i amerykańskich pacjentów z nieswoistymi chorobami zapalnymi jelit. Przegląd Gastroenterol. 2011; 6 (6): 388-400.

8. Scheridan C.L., Radmacher S.A.: Psychologia zdrowia. Wyzwanie dla biomedycznego modelu zdrowia. Instytut Psychologii Zdrowia. Warszawa 1998

9. Nowicki A., Ostrowska Ż.: Akceptacja choroby przez chore po operacji raka piersi w trakcie leczenia uzupełniającego. Pol. Merkuriusz Lek. 2008; 143: 5-9.

10. Pawlik M., Kaczmarek-Borowska B.: Akceptacja choroby nowotworowej u kobiet po mastektomii. Przegląd Medyczny Uniwersytetu Rzeszowskiego Narodowego Instytutu Leków w Warszawie. Rzeszów 2013, 2, 203-211.

11. Juczyński Z.: Narzędzia pomiaru w promocji i psychologii zdrowia. Polskie Towarzystwo Psychologiczne. Warszawa 2001.

12. Juczyński Z.: Narzędzia pomiaru w promocji i psychologii zdrowia. Pracownia Testów Psychologicznych. Warszawa 2009.

13. Glińska J., Grzegorczyk A., Dziki Ł., Dziki A.: Proces adaptacji do życia z nieswoistymi chorobami zapalnymi jelit. Probl. Pielęg. 2015; 23 (1): 7-12.

14. Stangierska I, Marcinkowska M, Horst-Sikorska W.: Problemy psychologiczne pacjentów z cukrzycą typ I. Nowiny Lekarskie. 2002; 71, 4-5; 212-216. 
15. Andruszkiewicz A., Kubica A., Nowik M.: Poczucie koherencji i poczucie własnej skuteczności jako wyznaczniki akceptacji choroby w grupie pacjentów przewlekle chorych. Problemy Pielęgniarstwa. 2014; 22: 239-245.

16. Butkiewicz A.M., Dymicka-Piekarska V., Kemona-Chętnik I.: Aktywacja płytek krwi w niestabilnej chorobie wieńcowej w zależności od stężenia troponiny I. Polski Merkuriusz Lekarski. 2005; 18 (103): 13-16.

17. Kaczmarczyk M.: Poziom akceptacji choroby osób starszych zamieszkujących w różnych środowiskach. Studia Medyczne. 2008; 12: 29-33.

18. Andrzejewska J., Talarska D., Michalak M., Linke K.: Quality of life In patients with Crohn's disease and ulcerative colitis. Comperative analysis. Przegl. Gastroenterol. 2009; 4 (5): 251-255.
19. Petryszyn P., Ziółkowska J., Paradowski L.: Nieswoiste zapalenia jelit w ubezpieczeniu rentowym - przegląd piśmiennictwa. Przegl. Gastroenterol. 2008; 3 (5): 237-242.

20. Bernklev T., JahnsenJ., Henriksen M. et al.: Relationship between sick leave, unemployment, disability, and health-related quality of life in patients with inflammatory bowel disease. Inflamm. Bow. Dis. 2006; 12: 402-412.

21. Bączyk G., Karoń J., Krokowicz P. et al.: Assessing quality of life among patients with inflammatory bowel disease treatment on surgical ward. Proktologia. 2008; 9: 172-182.

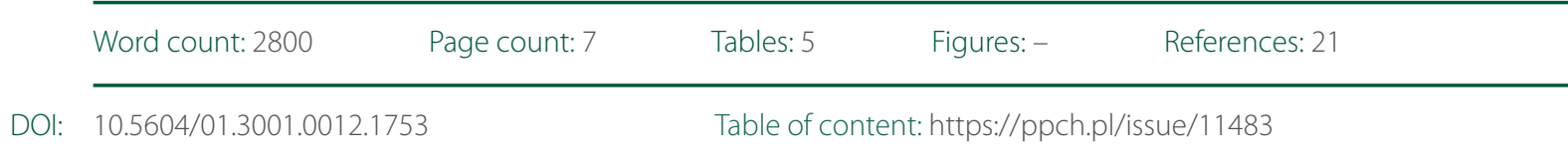

Copyright: Copyright @ 2018 Fundacja Polski Przegląd Chirurgiczny. Published by Index Copernicus Sp. z o. o. All rights reserved.

Competing interests: The authors declare that they have no competing interests.

2 The content of the journal "Polish Journal of Surgery" is circulated on the basis

- of the Open Access which means free and limitless access to scientific data.

This material is available under the Creative Commons - Attribution 4.0 GB. The full terms of this license are available on: http://creativecommons.org/licenses/by-nc-sa/4.0/legalcode

Corresponding author: Joanna Chrobak-Bień, Klinika Chorób Przewodu Pokarmowego, Uniwersytet Medyczny w Łodzi, Polska; Tel.: +48663668 460; E-mail: aska1105@interia.pl

Cite this article as: Chrobak-Bien J., Gawor A., Paplaczyk M., Malecka-Panas E., Gasiorowska A.: The influence of socio-demographic and clinical factors on the process of acceptance of the disease among patients with ulcerative colitis; Pol Przegl Chir 2018: 90 (6): 6-12 
